\title{
The Killing of General Quassem Soleimani: Legal and Policy Issues
}

\section{Boris Kondoch*}

On January 3, 2020, the Trump administration killed General Quassem Soleimani by a drone strike. Soleimani had been widely considered the second most powerful leader in Iran. President Trump and his administration have provided different justifications for the drone attack. The assassination of Quassem Soleimani has been met with criticism in many parts of the world. Legal scholars have extensively debated the lawfulness of the drone strike. They discussed, inter alia, whether the killing of the Iranian general was a violation of international law regulating the use of force (jus ad bellum), international humanitarian law (jus in bello) and international human rights law. The following article examines the legality of the killing of the Iranian general, from the jus ad bellum by focusing on the accumulation of events theory. Furthermore, the article addresses the policy implications that the killing of Soleimani might have on other countries such as North Korea.

\section{Keywords}

Quassem Soleimani, Drones, International Law, Jus ad Bellum, Pre-emptive Self-defence, Accumulation of Events Theory, Policy Implications, North Korea

Last night, at my direction, the United States military successfully executed a flawless precision strike that killed the number-one terrorist anywhere in the world, Qasem Soleimani. Soleimani was plotting imminent and sinister attacks on American

* Professor at Far East University, Korea; Editor of the Journal of International Peacekeeping (Brill). Diplom-Jurist (Johann Wolfgang Goethe-Univ.). ORCID: https://orcid.org/0000-0002-8318-6909. The author may be contacted at: kondoch@hotmail.com/Address: Far East University, Eumseong-gun, Chungcheonbuk-do 369-700 Korea. This article is dedicated to the memory of my father, Dr. Hartmut Kondoch. 
diplomats and military personnel, but we caught him in the act and terminated him.

US President Donald Trump ${ }^{1}$

The administration recently announced that, on orders of the president, the United States had "taken out" (which really means "murdered") an important military leader of a country with which we were not at war. ..., I view such immoral action as a clear violation of national and international law.

\section{Benjamin B. Ferencz (Nuremberg War Crimes Prosecutor) ${ }^{2}$}

\section{Introduction}

On January 3, 2020, the Trump administration ordered a drone strike near the Bagdad International Airport to kill Quassem Soleimani who was an Iranian major general in Iraq discussing with Iraq's prime minister how to improve the relationship between Iran and Saudi-Arabia. However, the US has rejected the claim that the Iranian commander was on a peace mission. ${ }^{3}$

Soleimani had been widely considered the second most powerful leader of Iran behind Iran's Supreme Leader, Ayatollah Ali Khamenei as well as the head of Iran's Quds force. The US killing of the top Iranian military leader and his colleagues ${ }^{4}$ has led to a controversial debate among Middle East policymakers and legal experts whether the killing was strategically and politically wise, morally and legally justifiable. Much of the discussion has focused on the implications for peace and stability worldwide and in the region.

The following article will address the killing from the perspective of international law ${ }^{5}$ and policy. It also turn to the question what kind of implications the killing of

1 See Remarks by President Trump on the Killing of Qasem Soleimani, The White House, Jan. 3, 2020, https://www. whitehouse.gov/briefings-statements/remarks-president-trump-killing-qasem-soleimani.

2 B. Ferencz, The 'Immoral' Killing of the Iranian General, N.Y. Times, Jan. 15, 2020, https://www.nytimes. com/2020/01/15/opinion/letters/us-iran-killing.html.

3 Staff writer, US Says Soleimani not on 'Diplomatic Mission' when He Was Killed, Euronews, Jan. 7, 2020, https:// www.euronews.com/2020/01/07/watch-live-us-secretary-of-state-mike-pompeo-speaks-after-iran-strike.

4 Amir Havasi, Iran Threatens Revenge as It Mourns Guards Killed by US, InT'L Bus. Times, Jan. 3, 2020, https://www. ibtimes.com/iran-threatens-revenge-it-mourns-guards-killed-us-2895702.

5 For details on the legal issues under the US law, see, e.g., S. Anderson, Did the President Have the Domestic Legal Authority to Kill Qassem Soleimani?, LAwfare, Jan. 3, 2020, https://www.lawfareblog.com/did-president-have- 
Soleimani might have on countries such as North Korea. This paper is composed of eight parts including Introduction and Conclusion. Parts two-four will try to determine the basic facts and gauge the reactions from the international community and legal experts. Part five will focus on the legality of the killing from the jus ad bellum. Parts six and seven will examine the policy implications in general and concerning North Korea.

\section{Basic Facts}

General Quassem Soleimani was the leader of the Iranian Revolutionary Guard Corps (IRGC) Quds Force. ${ }^{6}$ For Iran and its supporters, Soleimani was a national hero. After his death Iran's Supreme Leader Ayatollah Ali Khamenei declared him a "living martyr" of the revolution. ${ }^{7}$ He helped to expand Iran's influence in the region by creating and maintaining networks with proxy militias including Hezbollah in Lebanon, the Houthis in Yemen and the Palestinian Islamic Jihad in the Gaza strip. Some of these proxy forces and militias are designated terrorist groups by the US and the EU. The US President Trump called him the number one terrorist in the world ${ }^{8}$ and a monster being responsible for the deaths of hundreds of US servicemen. He has been described as an evil genius bearing responsibility for the killings of and atrocities committed against the US troops and innocent civilians throughout the Middle East. ${ }^{9}$ In 2011, Soleimani supported President Assad's brutal crackdown of the Syrian opposition. It is estimated that around 500,000 civilians got massacred, more than 13

domestic-legal-authority-kill-qassem-soleimani; J. Bellinger III, Does the U.S. Strike on Soleimani Break Legal Norms?, CFR IN BRIEF, Jan. 6, 2020, https:/www.cfr.org/in-brief/does-us-strike-soleimani-break-legal-norms; A. Dershowitz, Easy Call: The Strike on Soleimani Was Lawful, Wall St. J., Jan. 5, 2020, https://www.wsj.com/ articles/easy-call-the-strike-on-soleimani-was-lawful-11578261997; J. Goldsmith, The Soleimani Strike: One Person Decides, Lawfare, Jan. 3, 2020, https://www.lawfareblog.com/soleimani-strike-one-person-decides; and O. Hathaway, The Soleimani Strike Defied the U.S. Constitution, AtLantic, Jan. 4, 2020, https://www.theatlantic.com/ideas/ archive/2020/01/soleimani-strike-law/604417.

6 For details, see I. Black, General Qassem Suleimani Obituary, GuARDIAN, Jan. 5, 2020, https://www.theguardian.com/ world/2020/jan/05/general-qassam-suleimani-obituary.

7 See Soleimani, 'living martyr' who rose above Iran rifts, AFP, Jan. 7, 2020, https://www.france24.com/en/20200107soleimani-living-martyr-who-rose-above-iran-rifts.

8 K. Young, Trump Says 'It Doesn't really Matter' if Iranian General Posed an Imminent” Threat, WASH. Post, Jan. 14, 2020, https://www.washingtonpost.com/national-security/trump-says-it-doesnt-really-matter-if-iranian-general-posedan-imminent-threat/2020/01/13/c9f7ea1c-362e-11ea-9541-9107303481a4_story.html.

9 See, e.g., K. Sadjadpour, The Sinister Genius of Qassem Soleimani, Wall ST. J., Jan. 10, 2020, https://www.wsj.com/ articles/the-sinister-genius-of-qassem-soleimani-11578681560. 
million people got displaced and hundreds of hospitals and medical centers had been targeted during the conflict in Syria. The Syrian conflict has been "characterized by a complete lack of adherence to the norms of international law." 10 There have been many reports of crimes against humanity, war crimes, starvation sieges and the use of poison gas attacks.

\section{International Reactions}

The international reaction towards the elimination of the Iranian top general has been mixed. ${ }^{11}$ The Permanent Representative of the Islamic Republic of Iran to the United Nations characterized the assassination of Major General Quassem Soleimani "an obvious example of State terrorism and, as a criminal act, constitutes a gross violation of the fundamental principles of international law, including, in particular, those stipulated in the Charter of the United Nations, and thus entails the international responsibility of the United States."12 Iran's Supreme Leader Ayatollah Ali Khamenei threatened, "severe revenge awaits the criminals" behind the attack, declaring three days of national mourning. ${ }^{13}$ According to the Iranian Foreign Minister Javad Zarif, "the US bears responsibility for all consequences of its rogue adventurism," and "the US' act of international terrorism, targeting \& assassinating General Soleimani-the most effective force fighting Daesh (ISIS), Al Nusrah, Al Qaeda et al-is extremely dangerous \& a foolish escalation." 14 Iran has also expressed its intention to pursue war-crimes charges against Donald Trump and the US military at the International Criminal Court (ICC). ${ }^{15}$ Thousands of Iranians protested and called for revenge. Five days after the deadly drone strike, Iran conducted Operation "Martyr Soleimani” by

10 UN Human Rights Council, Report of the Independent International Commission of Inquiry on the Syrian Arab Republic. U.N. Doc. A/HRC/2869 (Feb. 5, 2015), at 1.

11 For an extensive list of states' reactions, see M. Ansasari \& B. Nußberger, Compilation of States' Reactions to U.S. and Iranian Uses of Force in Iraq in January 2020, Just SECuRITY, Jan. 22, 2020, https://www.justsecurity.org/68173/ compilation-of-states-reactions-to-u-s-and-iranian-uses-of-force-in-iraq-in-january-2020.

12 Letter dated 3 January 2020 from the Permanent Representative of the Islamic Republic of Iran to the United Nations Addressed to the Secretary-General and the President of the Security Council, U.N. Doc. S/2020/13 (Jan. 3, 2020), https://digitallibrary.un.org/record/3841925.

13 L. Doucet, Qasem Soleimani: US Kills Top Iranian General in Baghdad Air Strike, BBC, https://www.bbc.com/news/ world-middle-east-50979463.

14 Staff writer, Iran: 'US Bears Responsibility for all Consequences of Its Rogue Adventurism, NATION, Jan. 3, 2020, https://nation.com.pk/03-Jan-2020/iran-us-bears-responsibility-for-all-consequences-of-its-rogue-adventurism.

15 Neither the US, Iran nor Iraq are signatories to the 2002 Rome Statute which established the ICC. 
launching more than a dozen ballistic missiles against two military bases in Iraq, but no casualties were reported. ${ }^{16}$

The US airstrike has also been met with criticism in Iraq. Iraq's UN Ambassador Mohammed Hussein Bahr Aluloom called on the UN Security Council to condemn the US strike and assassination. ${ }^{17}$ The UN Secretary-General Guterres called for "maximum restraint" in wake of the targeted killing. ${ }^{18}$ The permanent members of the Security Council were divided over the issue. The British Prime Minister Boris Johnson refrained from any criticism. He did not want to comment on the strict legality of the strike because it was not a UK operation. ${ }^{19}$ While the UK simply called for calm, China, France and Russia expressed their concerns over the death of Soleimani. The Chinese Foreign Minister Wang Yi pointed out: "China pays high attention to the intensification of U.S.-Iran conflict, opposes the abuse of force in international relations, and holds that military adventures are unacceptable." He also added, that "China, Iran should stand together against "unilateralism and bullying." 20 The Chinese government stressed that the sovereignty of Iraq should be respected..$^{21}$ Russia criticized the killing as an adventurist step ${ }^{22}$ and a gross violation of international norms. ${ }^{23}$ According to the Russian Foreign Ministry spokeswoman Maria Zakharova, "the world is now confronted with a new reality" and "this new reality entails the killing of a representative of a government of a sovereign state, an official, these actions are completely devoid of any legal basis." ${ }^{24}$ The Russian Foreign Minister Sergey Lavrov told his US counterpart Mike Pompeo in a telephone

16 J. Rothwell et al., Top Cleric Urges Supporters not to Attack US as Donald Trump Says Regime Has Backed Down, TelEGRAPH, Jan. 8, 2020, https:/www.telegraph.co.uk/news/2020/01/08/iran-launches-missile-attack-us-bases-iraqlatest-news.

17 Staff writer, Iraq Calls on U.N. Security Council to Condemn U.S. 'Assassination,' WASH. Times, Jan. 6, 2020, https:// www.washingtontimes.com/news/2020/jan/6/iraq-calls-un-security-council-condemn-us-assassin.

18 Staff writer, UN Chief Calls for De-escalation across Gulf Region after Killing of Top Iranian General in US Airstrike, UN NEws, Jan. 3, 2020, https://news.un.org/en/story/2020/01/1054701.

19 Staff writer, Boris Johnson: Soleimani Had Blood of British Troops on His Hands, Al JAZEera, Jan. 9, 2020, https:// www.aljazeera.com/news/2020/01/boris-johnson-soleimani-blood-british-troops-hands-200108130824218.html.

20 Ankit Panda, After US Strike of Soleimani, China and Russia Coordinate at the UN, Diplomat, https://thediplomat. com/2020/01/after-us-strike-on-soleimani-china-and-russia-coordinate-at-un.

21 Staff writer, Netanyahu Lauds Trump for Killing of Iran's Soleimani, Says Israel Stands by US, Times of ISRAEL, Jan. 3 , 2020, https://www.timesofisrael.com/netanyahu-lauds-trump-for-killing-of-irans-soleimani-says-israel-stands-by-us.

22 Staff writer, France, Russia and China Condemn Slaying of Soleimani as a Destabilizing Act, Times of Israel, Jan. 3 , 2020, https://www.timesofisrael.com/france-russia-and-china-condemn-slaying-of-soleimani-as-a-destabilizing-act.

23 A. Borshchevskaya, Russian Reactions to the U.S. Strike on Soleimani, The Washington Institute for Near East Policy (Jan. 7, 2020), https://www.washingtoninstitute.org/policy-analysis/view/russian-reactions-to-the-u.s.-strike-onsoleimani.

24 Staff writer, Russian Senator Calls U.S. Killing of Top Iranian General 'Worst Case Scenario, ' Expects New U.S.-Iran Clashes, Moscow Times, Jan. 3, 2020, https://www.themoscowtimes.com/2020/01/03/russian-senator-calls-us-killingof-top-iranian-general-worst-case-scenario-expects-new-us-iran-clashes-a68805. 
conversation that "targeted actions by a UN member state to eliminate officials of another UN member state, and on the territory of a third sovereign country without its knowledge grossly violate the principles of international law and deserve condemnation." ${ }^{25}$ Germany, currently a non-permanent member of the UN Security Council showed some understanding but warned: "We are at a dangerous escalation point and what matters now is contributing with prudence and restraint to deescalation." 26

Conversely, the Israeli Prime Minister Netanyahu praised President Trump "worthy of all appreciation" for ordering the strike. ${ }^{27}$ While hardly anyone lamented the death of Soleimani, opposition parties in the US and the UK criticized the decision. In the US, the Democrats argued that President Trump should have asked for congressional approval. ${ }^{28}$ The leader of the Labour party in the UK, Jeremy Corbyn branded the drone attack 'illegal' because he considered the assassination of an official of a foreign government in a third country a violation of international law. ${ }^{29}$ The German government called for de-escalation and diplomatic solutions. Although the German government spokesperson, Ulrike Demmer acknowledged that the US decision to target him was a reaction to a whole series of military provocations by Iran, ${ }^{30}$ the German government did not take a clear stance on the legality of the drone strike. It did not follow the legal opinion of the Scientific Service of the German Bundestag arguing that the killing of General Soleimani and his entourage could not be justified under international law. ${ }^{31}$ Eight German law makers from the Left Party expressed the view that the killing of Soleimani constituted a violation of international law. They have even filed a criminal complaint against the German

25 Ministry of Foreign Affairs of Russia, Press Release on Foreign Minister Sergey Lavrov's Telephone Conversation with US Secretary of State Mike Pompeo, Jan. 3, 2020, https://www.mid.ru/en/foreign_policy/news/-/asset_publisher/ cKNonkJE02Bw/content/id/3989636.

26 R. Frazin, World Reacts with Alarm after US Killing of Top Iran General, HiLl, Jan. 3, 2020; Germany on Soleimani Assassination: We Are at a Dangerous Escalation Point, Jan. 3, 2020, https://news.am/eng/news/552823.html.

27 Staff writer, Netanyahu Praises Trump for U.S. Strike on Soleimani, YNET, Jan. 5, 2020, https://www.ynetnews.com/ article/BJRPK4yxI.

28 W. Roberts, Was Trump's Order to Assassinate Iran's Qassem Soleimani Legal?, Al JAZEerA, Jan. 4, 2020, https:// www.aljazeera.com/news/2020/01/trump-order-assassinate-iran-qassem-soleimani-legal-200103212119366.html.

29 A. Evans, Jeremy Corbyn Says Killing of Qassem Soleimani Was 'Illegal'-and Refuses to Condemn Him as a Terrorist, INEWs, https://inews.co.uk/news/politics/jeremy-corbyn-sky-news-interview-killing-qassem-soleimani-illegal-refusescondemn-terrorist-iran-1358464.

30 Staff writer, U.S. Strike against Soleimani Was Reaction to Iran Provocations: Germany, Reuters, Jan. 3, 2020, https:// www.reuters.com/article/us-iraq-security-germany/us-strike-against-soleimani-was-reaction-to-iran-provocationsgermany-idUSKBN1Z20YU.

31 Wissenschaftliche Dienste Deutscher Bundestag, Völkerrechtliche Aspekte des Konflikts zwischen Iran und den USA, WD 2-3000-001/20, Jan. 13, 2020, https://www.bundestag.de/resource/blob/677272/ba6f4e61c1f5b534f3a2ef59db1e7 21e/WD-2-001-20-pdf-data.pdf. <available only in German> 
government for aiding by omission the murder of Qassem Soleimani, Abu Mahdi al Muhandis and other persons pursuant to Sections 211, 27, 13 of the German Criminal Code. ${ }^{32}$ They assume that the drone strike had been conducted from the Ramstein air base in Germany.

\section{Reactions of International Law Scholars}

Many analysts condemned the drone strike and labelled the killing an assassination, an act of state terrorism, pre-emptive assassination or simply murder. ${ }^{33}$ The majority of legal commentators including the Scientific Service of the German Bundestag questioned the legality of the drone strike. ${ }^{34}$ However, it is noteworthy that many legal experts when analyzing the killing of the Iranian commander arrived at very different conclusions, as to why the drone strike was a violation of international law. When addressing the jus ad bellum, one group of scholars only focused on the right to pre-emptive self-defence, while another group discussed the accumulations of events

32 The criminal complaint against Federal Chancellor (Bundeskanzlerin) Dr Angela Merkel, Federal Minister for Foreign Affairs (Bundesminister des Auswärtigen) Heiko Maas, Federal Minister of Defence (Bundesministerin der Verteidigung) Annegret KrampKarrenbauer, Federal Minister of the Interior (Bundesminister des Innern) Horst Seehofer, other members of the German Government and all other parties can be found at https://neu-alexander.de/ files/2020/02/Strafanzeige- $\%$ C3\%9Cbersetzung-Sprachendienst-mit-Formatkorrekturen.pdf.

33 M. Kennedy \& J. Northam, Was It Legal for The U.S. to Kill A Top Iranian Military Leader?, NPR, Jan. 4, 2020, https:// www.npr.org/2020/01/04/793412105/was-it-legal-for-the-u-s-to-kill-a-top-iranian-military-leader; H. Hongju Koh, Is Preemptive Assassination the New Trump Doctrine?, ForeIGn PoL'Y, Jan. 9, 2020, https://foreignpolicy.com/2020/01/09/ preemptive-assassination-suleimani-new-trump-doctrine-legal; J. Stavridis, Time to Brace for the Unintended Consequences of Killing Soleimani, JAPAN TIMES, Jan. 7, 2020, https://www.japantimes.co.jp/opinion/2020/01/07/ commentary/world-commentary/time-brace-unintended-consequences-killing-soleimani/\#.XlHSwigzaUk. For an interesting article on how the US presidents used different terms for political killings, see C. Carpenter, Assassination, Extrajudicial Execution, or Targeted Killing-What's the Difference?, ForeIGn PoL'y, Jan. 10, 2020, https://foreignpolicy. com/2020/01/10/targeted-killing-assassination-extrajudicial-execution-targeted-killing-illegal-trump-iran-suleimani.

34 See, e.g., Kai Ambos, Die Tötung Soleimanis als Belastungsprobe für das Völkerrecht, Frankfurter Allgemeine, EINSPRUCH, Jan. 8, 2020, https://www.faz.net/einspruch/die-toetung-soleimanis-als-belastungsprobe-fuer-dasvoelkerrecht-16571225.html; H. Aust, Die Tötung von Qassem Soleimani. Völker-und verfassungsrechtliche Fragen, VerfassungSBlog, Jan. 5, 2020, https://verfassungsblog.de/die-toetung-von-qassem-soleimani; A. Callamard, The Targeted Killing of General Soleimani: Its Lawfulness and Why It Matters, Jan. 8, 2020, https://www.justsecurity. org/67949/the-targeted-killing-of-general-soleimani-its-lawfulness-and-why-it-matters; M. Ellen O'Connell, The Killing of Soleimani and International Law, EJIL: TALK!, Jan. 6, 2020, https://www.ejiltalk.org/the-killing-of-soleimani-andinternational-law; A. Gurmendi, Raising Questions on Targeted Killings as First Strikes in IACs, OpINIO JurIs, Jan. 9 , 2020, http://opiniojuris.org/2020/01/09/raising-questions-on-targeted-killings-as-first-strikes-in-iacs; M. Milanovic, The Soleimani Strike and Self-Defence against an Imminent Armed Attack, EJIL: TALK!, Jan. 7, 2020, https://www.ejiltalk. org/the-soleimani-strike-and-self-defence-against-an-imminent-armed-attack; S. Katharina Stein, The Targeted Killing of Qassem Soleimani-a Short Recapitulation, Völkerrechtsblog, Jan. 10, 2020, https://voelkerrechtsblog.org/the-targetedkilling-of-qassem-soleimani-a-short-recapitulation. 
theory additionally. Some scholars including Eliav Lieblich argued that international humanitarian law should apply, ${ }^{35}$ while others such as Mary Ellen O'Connell did not consider it all but analyzed the case from a human rights angle. ${ }^{36}$ One of the major problems making the Soleimani case so difficult and complex is the fact that as of October 2020 not all relevant information was disclosed yet by the Trump administration. In addition, contradictory statements concerning the rationale for the drone strike have been provided by senior US officials. ${ }^{37}$ The legal issues will now be explored in the following paragraphs.

\section{Targeted Killings by Drones and International Law}

For the last twenty year, a number of states including the UK, the US as well as NATO have used drones in their military operations. Drones provide an important military advantage because they can kill enemies from thousands of miles away, without risking and endangering the lives of a country's own forces. Since the attacks of September 11, various US administrations under President Bush, Obama and Trump have used drones in its "War on Terror" for targeted killing in places like Afghanistan, Iraq and Yemen. In general, one may define a targeted killing as "the intentional, premeditated and deliberate use of lethal force, by States or their agents acting under colour of law, or by an organized armed group in armed conflict, against a specific individual who is not in the physical custody of the perpetrator." 38 What makes the Soleimani case different is the fact that Quassem Soleimani was a state official and not a non-state actor like Osama Bin Laden and Abu Bakr Al-Baghdadi, the leader of ISIS in previous US drones strikes against terrorists. ${ }^{39}$ The speaker of

35 E. Lieblich, Targeted Killing of General Soleimani: Why the Laws of War Should Apply, and Why it Matters, JUST SECURITY, Jan. 13, 2000, https://www.justsecurity.org/68030/targeted-killing-of-general-soleimani-why-the-laws-ofwar-should-apply-and-why-it-matters.

36 O'Connell, supra note 34.

37 E. Kiely, Trump Administration's Shifting Statements on Soleimani's Death, Jan. 15, 2020, https://www.factcheck. org/2020/01/trump-administrations-shifting-statements-on-soleimanis-death.

38 P. Alston, Report of the Special Rapporteur on Extrajudicial, Summary or Arbitrary Executions, Addendum, 'Study on Targeted Killings,' UN Human Rights Council, U.N. Doc. A/HRC/14/24/Add. 6 (May 28, 2010), https://www2.ohchr. org/english/bodies/hrcouncil/docs/14session/A.HRC.14.24.Add6.pdf.

39 For the legality of these drone attacks, see, e.g., K. Ambos \& J. Alkatout, 'Has 'Justice Been Done'? The Legality of Bin Laden's Killing under International Law, 45 Israel L. Rev. 341-66 (2012); L. Beres, Targeting Abu Bakr alBaghdadi: Pertinent Issues of Law and Strategy, SMALL WARS J., https://smallwarsjournal.com/jrnl/art/targeting-abubakr-al-baghdadi-pertinent-issues-law-and-strategy. On targeted killings, see generally J. Cerone, The Legality of the Killing of Osama bin Laden, 107 Am. Soc. Int'L L. Procs.: International Law in a Multipolar World 47-51 (2013). 
the US House of Representatives, Nancy Pelosi argued that the killing of Soleimani would be comparable to Iran taking out the US Vice President Mike Pence. ${ }^{40}$

The use of drones has come under harsh criticism, since drones have also killed a great number of innocent civilians despite their precision. ${ }^{41}$ The Bureau of Investigative Journalism estimates that US drones killed 2,181 civilians in Afghanistan, Pakistan, Somalia and Yemen from 2004 to March 2020. ${ }^{42}$ Another concern about the use of armed drones for targeting human beings is the alleged "Play Station" or "push button" mentality whereby operators do not consider the targets as human beings but as merely bleeps on a screen because of the geographical and psychological distance. ${ }^{43}$ Human rights organizations have criticized that drone strikes may amount to extrajudicial killings and war crimes in some cases. For the human rights lawyer, Geoffrey Robertson, "drone attacks go against every human rights principle in the book." ${ }^{44} \mathrm{He}$ accuses the Pentagon for secretly sentencing people to death for an unproven crime. As pointed out by the UN Special Rapporteur on Extra-Judicial Executions, Agnès Callamard: "Outside the context of active hostilities, the use of drones or other means for targeted killing is almost never likely to be legal." " However, there are also experts like international law professor Kenneth Anderson who rejects many of the ethical and legal objections and view drone warfare as an effective tool in the US counterterrorism strategy. ${ }^{46}$

It needs to be stressed that international law does not prohibit targeted killings by drones as long as certain legal criteria are fulfilled. ${ }^{47}$ When analyzing the lawfulness of the killing of general Soleimani, one has to identify first the applicable legal framework, which may be found in the so-called jus ad bellum (the conditions under which States may resort to war or to the use of armed force in general), ${ }^{48}$ the so-called

40 S. Carter, Pelosi: Killing Soleimani Would Be like Killing the '2nd Most Important Person in the' USA, https:// saraacarter.com/pelosi-killing-soleimani-would-be-like-killing-the-2nd-most-important-person-in-the-usa.

41 For a critical account of drone warfare, see generally L. Calhoun, We Kill because We Can: From Soldiering to Assassination in the Drone Age (2016).

42 The Bureau of Investigative Journalism, Drone Warfare, https://www.thebureauinvestigates.com/projects/drone-war.

43 For details, see C. Cole, Convenient Killing: Armed Drones and the 'Playstation' Mentality (Sept. 2010), https:// dronewarsuk.files.wordpress.com/2010/10/conv-killing-final.pdf.

44 G. Robertson, Drone Attacks Go against Every Human Rights Principle in the Book. There Is a Sense that International Law Has Failed, New Statesman, June 13, 2012, https://www.newstatesman.com/lifestyle/lifestyle/2012/06/droneattacks-against-human-rights-principle-book.

45 Agnès Callamard on twitter, https://twitter.com/agnescallamard/status/1212918159096864768.

46 For details, see K. Anderson, The Case for Drones, Commentary, June 2013, https://www.commentarymagazine.com/ articles/anderson-kenneth/the-case-for-drones.

47 For overviews, see G. Nolte, Targeted Killing, in Max Planck Encyclopedia of Public International Law (2011); M. Wagner, Unmanned Aerial Vehicles, in Max Planck Encyclopedia of Public International Law (2014).

48 ICRC, What are jus ad bellum and jus in bello?, https://www.icrc.org/en/document/what-are-jus-ad-bellum-and-jus- 
jus in bello (regulation for the conduct of parties engaged in an armed conflict) ${ }^{49}$ and international human rights law. The following article addresses the killing from the perspective of the jus ad bellum.

\section{Jus ad Bellum}

The use of force is in general prohibited by postwar international law. According to Article 2(4) of the UN Charter, "All Members shall refrain in their international relations from the threat or use of force against the territorial integrity or political independence of any state, or in any other manner inconsistent with the purposes of the United Nations." Article 2(4) is the central norm of the UN Charter which prohibit not only armed measures to settle international disputes, but also illegal threats of force. Article 2(4) of the UN is considered a rule of customary international law and a preemptory norm of international law (jus cogens). There are only two undisputed exceptions to Article 2(4) of the UN Charter: (1) UN Security Council authorizations under Chapter VII of the UN Charter and (2) the right to individual or collective selfdefence under Article 51 of the UN Charter.

President Trump and his administration have provided different justifications for the drone attack. The Department of Defense stated: "At the direction of the President, the U.S. military has taken decisive defensive action to protect U.S. personnel abroad by killing Qasem Soleimani [...]. General Soleimani was actively developing plans to attack American diplomats and service members in Iraq and throughout the region." ${ }^{, 50}$ Secretary of State Mike Pompeo explained: "The "decision to eliminate Soleimani" was "in response to imminent threats to American lives." President Trump said: "Soleimani was plotting imminent and sinister attacks on American diplomats and military personnel, but we caught him in the act.,

Instead of relying on the right to pre-emptive self-defence, however, the US

bello- 0 .

49 Id.

50 Statement by the Department of Defense, Jan. 2, 2020, https:/www.defense.gov/Newsroom/Releases/Release/Article/ 2049534/statement-by-the-department-of-defense.

51 See Mike Pompeo on twitter, https://twitter.com/secpompeo/status/1213062846021558273?lang=de; C. Cameron \& H. Cooper, The Trump Administration's Fluctuating Explanations for the Suleimani Strike, N.Y. Tımes, Jan. 12, 2020, https:/www.nytimes.com/2020/01/12/us/politics/trump-suleimani-explanations.html.

52 Remarks by President Trump on the Killing of Qasem Soleimani, Jan. 3, 2020, https://www.whitehouse.gov/briefingsstatements/remarks-president-trump-killing-qasem-soleimani. 
explained in a letter to the UN that it had acted pursuant to Article 51 of the UN Charter "in response to an escalating series of armed attacks in recent months by the Islamic Republic of Iran and Iran-supported militias on U.S. forces and interests in the Middle East region, in order to deter the Islamic Republic of Iran from conducting or supporting further attacks against the United States or U.S. interests, and to degrade the Islamic Republic of Iran and Islamic Revolutionary Guard Corps Qods Forces supported militias' ability to conduct attacks. ${ }^{, 53}$ The letter also mentioned:

a) a threat to the amphibious ship USS BOXER on July 18, 2019,

b) as an armed attack on June 19, 2019, by an Iranian surface-to-air missile on an unmanned U.S. Navy MQ-4 surveillance aircraft,

c) attacks on commercial vessels off the port of Fujairah and in the Gulf of Oman,

d) missile and unmanned aircraft attacks on the territory of Saudi Arabia,

e) and a series of attacks against U.S. forces by Qods Force-backed militia groups in Iraq, including Kata'b Hizballah (one attack led to the death of a U.S. Government contractor and injury to four U.S. service members).

Following the International Court of Justice (ICJ), it is not admissible "to ascribe to States legal views which they do not themselves formulate." out by the Court, one must distinguish between "justifications solely advanced in a political context" and those "advanced as legal arguments." Therefore, only the legal justifications reported to the UN will be analyzed in the next paragraphs. From the perspective of international law, one may ask the following questions: Did the abovementioned incidents amount to an armed attack in accordance with Article 51 of the UN Charter? Have they been escalating and ongoing? Can they be attributed to Iran and General Soleimani? Was the use of force necessary and proportionate?

The right of self-defence which is also a rule of customary international law is enshrined in Article 51 of the UN Charter. The key question is whether the incidents described in the letter to the UN amount to armed attacks. The UN Charter provides no definition of the term "armed attack." Following the ICJ, not every use of force should be viewed as an armed attack. Only uses of force, which are of a particular scale and effect, are considered armed attacks. Mere border incidents are outside the scope of Article 51 of the UN Charter. ${ }^{56}$

$53 \quad$ Id.

54 Military and Paramilitary Activities in and against Nicaragua (Nicar. v. U.S.), Judgment, 1984 I.C.J. Rep. 134, 9266 (June 27).

55 Id.

56 Military and Paramilitary Activities in and against Nicaragua (Nicar. v. U.S.), Judgment, 1984 I.C.J. Rep. 176, ๆ 195 (Nov. 26). 
Arguably, most of the above-mentioned incidents were not significant uses of force. However, the US appears to legally justify the killing with the so-called "needle-prick" or "accumulation of events" theory or in German 'Nadelstichtaktik,' even though the letter does not explicitly make reference to it. According to this legal rationale, a number of small-scale attacks may not independently amount to an armed attack, but can be viewed collectively reaching the threshold of an armed attack under Article 51 of the UN Charter. The ICJ has considered the accumulation of events theory in a number of cases, but has never discussed the exact legal parameters when accumulating events would collectively amount to an armed attack. ${ }^{57}$ Whether the accumulation of events theory is part of customary international law is open to debate. The theory is of particular relevance in the context of cyber-attacks, which do often not amount, per se to armed attacks and in regard to low intensity attacks by terrorist organizations. ${ }^{58}$ Proponents of this legal doctrine have been Israel and the US. Despite the growing support by scholars in recent years, one may wonder what the exact legal criteria of this theory are.

Actually, the accumulation of events theory is problematic for two reasons. One is that there is the inherent risk of abuse because of "the manifest danger of circumvention of the gravity and immediacy elements of armed attack." is that the theory could lead to an open-ended license to use force and a permanent state of self-defence. ${ }^{60}$ Arguably, certain conditions need to be satisfied before the accumulation of events theory applies to the case of General Soleimani. There must be a linkage of a series of incidents in time, space and source. ${ }^{61}$

The legal justifications provided in the letter to the UN are highly problematic. Threats like the one to the amphibious ship USS BOXER do not amount to armed attacks according to Article 51 of the UN Charter. The letter does not explain how the attacks by the Quds Force-backed militia groups could be attributed to Iran. How can the missile and unmanned aircraft attacks on the territory of Saudi Arabia trigger the right to self-defence of the US? Most importantly, as remarked by the Special

57 Nicaragua case, supra note 54. ๆ 231. See also Oil Platforms (Iran v. U.S.), Judgment, 2003 I.C.J. Rep. ๆ 64 (Nov. 6); Case Concerning Armed Activities on the Territory of the Congo, Judgment, 2005 I.C.J. Rep. 146 (Dec. 19).

58 See, e.g., H. Dinniss, Cyber Warfare and the Laws of War 93-5 (2012); C. Tams, The Use of Force against Terrorists, 20 Eur. J. INT'L L. 387-91 (2009).

59 A. Randelzhofer \& G. Nolte, Article 51, in The Charter of the United Nations: A Commentary 1409 (B. Simma et al. eds., 2012).

60 Id. For details on the accumulation of events theory, see T. RuYs, Armed ATtACK' AND ARTicle 51 of the UN ChARTER 168-75 (2010).

61 S. Talmon \& M. Heipertz, The U.S. Killing of Iranian General Qasem Soleimani: Of Wrong Trees and Red Herrings, and Why the Killing May Be Lawful after All, 8 (Bonn Research Papers on International Law No. 18, 2020). 
Rapporteur on extrajudicial, summary or arbitrary executions, Agnès Callamard, ${ }^{62}$ the letter simply refers to past and separate events, which are not necessarily connected to each other. To date, the US has failed to provide any evidence that these attacks are ongoing and escalating. Furthermore, the letter to the UN fails to show that the killing of General Soleimani and several others complied with the legal requirements of proportionality and necessity. One important question remains: Had there been no alternative to the drone strike? Therefore, the killing of General Soleimani by the US cannot be justified under Article 51 of the UN Charter. As to the author's best knowledge, the Trump administration did not provide any legal reasons why the US conducted the done strike on Iraqi territory.

\section{Policy Considerations: North Korea}

Arguably, there will be long-term implications for peace and stability in the Middle East and the entire world. ${ }^{63}$ It remains unclear how Iran will further respond economically, militarily and asymmetrically to the US drone attack. ${ }^{64}$ Will the US get closer to engaging in another endless war? What is the long term strategy of the US for Iran and the entire region? Another important question concerns how the US and its allies will co-operate and co-ordinate on intelligence, military and diplomatic matters with each other in the future.

Analysists are also wondering what kind of impact the US strike could have on North Korea and future nuclear talks: Will the North Korea nuclear weapons issue be pushed down on President Trump's list of priorities because of the developments in the Middle East? Will North Korea see the killing of the Iranian general as a warning? Will the North Korean leadership become more cautious and less provocative? Will Kim Jong Un be the potential subject of a future assassination attempt by the US? Will

62 Special Rapporteur on Extrajudicial, Summary or Arbitrary Executions, Extrajudicial, Summary or Arbitrary Executions, U.N. Doc. A/HRC/44/38 (June 29, 2020), 157.

63 S. Vakil, R. Mansour \& L. Khatib, How the Soleimani Assassination Will Reverberate throughout the Middle East, Jan. 6, 2020, https:/www.chathamhouse.org/expert/comment/how-soleimani-assassination-will-reverberate-throughoutmiddle-east?gclid=EAIaIQobChMI5Zn6jLaA6AIVyaiWCh1pDwOzEAAYASAAEgIAy_D_BwE.

64 For details, see D. Sabbagh, Iran Will Feel It Must Retaliate against US, Say Military Analysts, GuARDIAN, Jan. 5, 2020, https://www.theguardian.com/world/2020/jan/05/iran-will-feel-it-must-retaliate-against-us-say-military-analysts; I. Goldenberg, Will Iran's Response to the Soleimani Strike Lead to War? What Tehran Is Likely to Do Next, Jan. 3, 2020, ForeIGN AFF., https://www.foreignaffairs.com/articles/iran/2020-01-03/will-irans-response-soleimani-strike-leadwar; K. Johnson \& L. Seligman, Suleimani Killing Sparks Fear of War and Economic Turmoil, ForeIGn PoL'y, https:// foreignpolicy.com/2020/01/03/suleimani-killing-sparks-fear-of-war-and-economic-turmoil. 
North Korea return to diplomatic talks and eventually give up its nuclear programme or will the diplomatic efforts be an indirect casualty of the US air strike? ${ }^{65}$ We can only speculate what kind of lessons, if any, Kim Jung Un and the North Korean military leadership have learned from the elimination of General Soleimani. North Korea's tightly controlled state media has reported relatively little on the killing of General Quassem Soleimani and did not publish any direct criticism. ${ }^{66}$ According to Rachel Minyoung, a senior analyst at NK Pro, this shows that the killing of the Iranian general is a sensitive issue. ${ }^{67}$ For the well-known North Korea specialist, Andrei Lankov, North Korea might take it as sign that President Trump is not a paper tiger and "not just a lover of empty bellicose talk but somebody who can use force." " In a policy speech delivered at the beginning of January 2020, the North Korean leader, Kim Jong Un expressed his intention that his regime would never give up its nuclear arsenal. He also announced that the world would witness a new strategic weapon in the near future. ${ }^{69}$ On March 2, 2020, North Korea fired two missiles towards the East Sea and few days later, on March 9, 2020, the DPRK shot at least three projectiles. Arguably, the killing of Soleimani might reaffirm this policy that the DPRK can only survive if it possesses nuclear weapons. Kim Jong Un might even fear that he could be next on the list. In the words of Donald Kirk, he might wonder: What good are my nukes ... against drone strikes that could kill me any time? ${ }^{70}$

65 So-Hyun Kim, US Drone Strike Expected to Negatively Impact N. Korea-US Negotiations, HanKYoREH, Jan. 6, 2020, http://english.hani.co.kr/arti/english_edition/e_northkorea/923341.html; Tong-Hyung Kim, US Strike on Iran Could Have Consequences in North Korea, AP News, Jan. 7, 2020, https://apnews.com/b6b5f79d170628a0db384f9374ca9 83f; A. Lankov, What the U.S. Killing of Iran's Top General Means for North Korea, NK News, Jan. 5, 2020, https:// www.nknews.org/2020/01/what-the-u-s-killing-of-irans-top-general-means-for-north-korea; K. Graca Peters, Paranoia in Pjoengjang, Jan. 13, 2020, SPIEGEL, https://www.spiegel.de/politik/ausland/nordkorea-und-die-iran-krise-paranoia-inpjoengjang-a-5b9c9c6d-6834-47da-8144-0507306aad4f; Steffen Richter, Hält Kim Jong Un weiter still?, Zerт, Jan. 9 , 2020, https://www.zeit.de/politik/ausland/2020-01/atomstreit-iran-nordkorea-usa-donald-trump-kim-jong-un.

66 S. Denyer, Why North Korea's State Media Has Barely Mentioned U.S. Killing of Iran's Soleimani, WASH. Post, Jan. 7, 2020, https://www.washingtonpost.com/world/asia_pacific/why-north-koreas-state-media-has-barely-mentioned-uskilling-of-irans-soleimani/2020/01/07/e53f7c28-30fb-11ea-971b-43bec3ff9860_story.html.

67 Id.

68 Id.

69 D. Cole \& L. Register, Kim Jong Un Warns Hostile US Policy Means There Will Never Be Denuclearization on Korean Peninsula, CNN, Jan. 2, 2020, https://edition.cnn.com/2019/12/31/politics/north-korea-kim-jong-un-us-policydenuclearization/index.html.

70 D. Kirk, Assassination or Decapitation? U.S. Gets Kim Jong-un's Attention, Inside Source, Jan. 14, 2020, https://www. insidesources.com/assassination-or-decapitation-u-s-gets-kim-jong-uns-attention. 


\section{Conclusion}

The illegality of the drone led killing of General Soleimani may have also long-term consequences for whether the international order is governed by the rule of law or the rule of the jungle. ${ }^{71}$ It appears that international law has not played a major role in the decision-making process by the Trump administration. Until now, the Trump administration has not provided any clear evidence for an imminent attack. Claims that the Iranian general was plotting to attack four US embassies could not be confirmed. Shortly after the drone-led killing Donald Trump argued "whether or not the future attack by terrorist Soleimani was 'imminent' or not ... doesn't really matter because of his horrible past!" "72 A lack of understanding of and respect for international law by the US President Trump has become a growing concern among legal observers. ${ }^{73}$ During the 2017 crisis, President Trump gave a speech at the UN threatening to totally destroy North Korea. ${ }^{74}$ During the January 2020 crisis with Iran he even threatened to attack 52 preselected Iranian cultural sites (representing the 52 US hostages taken by Iran in 1079) if Iran retaliated for Soleimani's death: "Let this serve as a warning that if Iran strikes any Americans, or American assets, we have ... targeted 52 Iranian sites, some at a very high level \& important to Iran \& the Iranian culture, and those targets, and Iran itself, will be hit very fast and very hard." ${ }^{, 5}$ Targeting cultural property would be in clear violation of The Hague Convention of 1954 (Articles 2-4) and targeting civilian objects would be in violation of the Additional Protocol 1 to the Geneva Conventions (Articles 48 \& 52).

The US Presidential election was just over and Democrat candidate Joe Biden will take office early 2021. The new administration is expected to be back to international law for Middle East and North Korean questions.

71 J. Dorsey, Killing Quassim Soleimani: Rule of Law of the Jungle?, Modern Diplomacy, Jan. 7, 2020, https:// moderndiplomacy.eu/2020/01/07/killing-qassim-soleimani-rule-of-law-or-rule-of-the-jungle.

72 B. Gittleson, Doesn't really Matter': Trump on whether Threat from Iranian General 'Imminent.' The Explanations from Trump and Top Officials Have Shifted Multiple Times, ABC News, Jan. 14 2020, https://abcnews.go.com/Politics/ accounts-intelligence-triggered-killing-irans-top-general-totally/story?id=68255236.

73 See, e.g., H. Hongu Koh, The Trump Administration and International Law (2018), C. Schaller, America First-Wie Präsident Trump das Völkerrecht strapaziert, SWP-Studie 2019/S, Dec. 27, 2019, https://www.swp-berlin.org/ publikation/america-first-wie-praesident-trump-das-voelkerrecht-strapaziert; S. Talmon, The United States under President Trump: Gravedigger of International Law, 18 CHINESE J. INT’L L. 645-68 (2019).

74 A. Lichterman \& J. Burroughs, Trumps Threat of total Destruction is Unlawful and Extremely Dangerous, IPS, Sept. 17, 2017, http://www.ipsnews.net/2017/09/trumps-threat-total-destruction-unlawful-extremely-dangerous.

75 Donald J. Trump on twitter, Jan. 5, 2020, https:/twitter.com/realdonaldtrump/status/1213593975732527112?lang=de. 
434 Boris Kondoch

Received: August 1, 2020

Modified: October 30, 2020

Accepted: November 15, 2020 